\title{
太平洋島嶼域におけるマングローブ林の立地形成と海水準変動
}

\author{
藤本 潔 森林総合研究所森林環境部 $\overline{7} 305$ 茨城県稲敷郡茎崎町松の里 1
}

\section{Mangrove habitat evolution related to Holocene sea-level changes on Pacific islands}

Kiyoshi FuJIMOTO Forest Environment Division, Forestry and Forest Products Research Institute, P.O. Box 16, Tsukuba Norin Kenkyu Danchi-Nai, Ibaraki 305, Japan

\begin{abstract}
Geomorphological evolutions of mangrove habitats on the Pacific islands and prediction of the habitat dynamics were discussed using the examples of Kosrae Island in Micronesia, Bohole Island in the Philippines and Iriomote and Ishigaki Islands belonging to the Yaeyama Islands in Japan.

Most of the mangrove forests of Kosrae have been developed during the last 2000 years by accumulating mangrove peat with the gradual sea-level rise of 1 to $2 \mathrm{~mm} / \mathrm{yr}$. During the period of rapid sea-level rise of about $10 \mathrm{~mm} / \mathrm{yr}$ between 4100 and $3700 \mathrm{yr}$ B.P., the mangrove forests ceased peat accumulation and retreated landward. These evidences suggest that the critical rate of mangrove peat accretion with sea-level rise is between $2 \mathrm{~mm} / \mathrm{yr}$ and $10 \mathrm{~mm} / \mathrm{yr}$. If the velocity of the anticipated sealevel rise exceeds the critical rate, all of the mangrove forests of Kosrae will retreat landward and reduce rapidly.

The mangrove habitats on Bohole Island have been formed by the same processes as on Kosrae Island except the expansion of clay layer overlying a mangrove peat layer during the last several hundred years. The clay deposit, which was inferred to have derived from the deforested slopes, supported Nypa fruticans thicket. Rapid sea-level rise over the critical rate of the mangrove peat accumulation will induce the retreat of mangrove forests from their seaward margin, however, the invasion of mangrove trees into the Nypa habitat will not occur immediately because the habitat conditions of the clay deposited area is no longer suitable for the growth of mangrove species except Nypa.

Mangrove habitats of Iriomote and Ishigaki Islands abruptly moved seaward by a relative sea-level fall that occurred about 1000 and 2000 yr B.P., apparently caused by seismic uplift. The thickness of the layers containing mangrove organic materials in present mangrove habitats were less than $1 \mathrm{~m}$. The organic layers have deposited during the last several hundred years. During the last few decades, input of sediments caused by soil erosion has affected the seaward expansion of mangrove forests. However, the sediments supply will result the reduction of mangrove area because the seaward limit of mangrove expansion is restricted by the geomorphological framework.
\end{abstract}

Key Words: geomorphological study / mangrove / habitat evolution / sea-level change / Micronesia / Philippine / Yaeyama Islands (地形学的研究 / マングローブ/立地形成/海水準変動 / ミクロ ネシア/フィリピン/八重山諸島）

マングローブ林は熱帯・亜熱帯の潮間帯に成立する森林で, 波浪や高潮から海岸線を守る海岸防 備林として，また水産資源の涵養の場としてなど，内陸の森林とは異なる特有の機能を有する。 しかし，近年の過度の伐採や養殖池への転用，あるいは集水域の開発に伴う土砂流入量の増大等 の影響で, マングローブ林の立地環境は悪化の一途をたどっている。また, 将来には温暖化に伴 


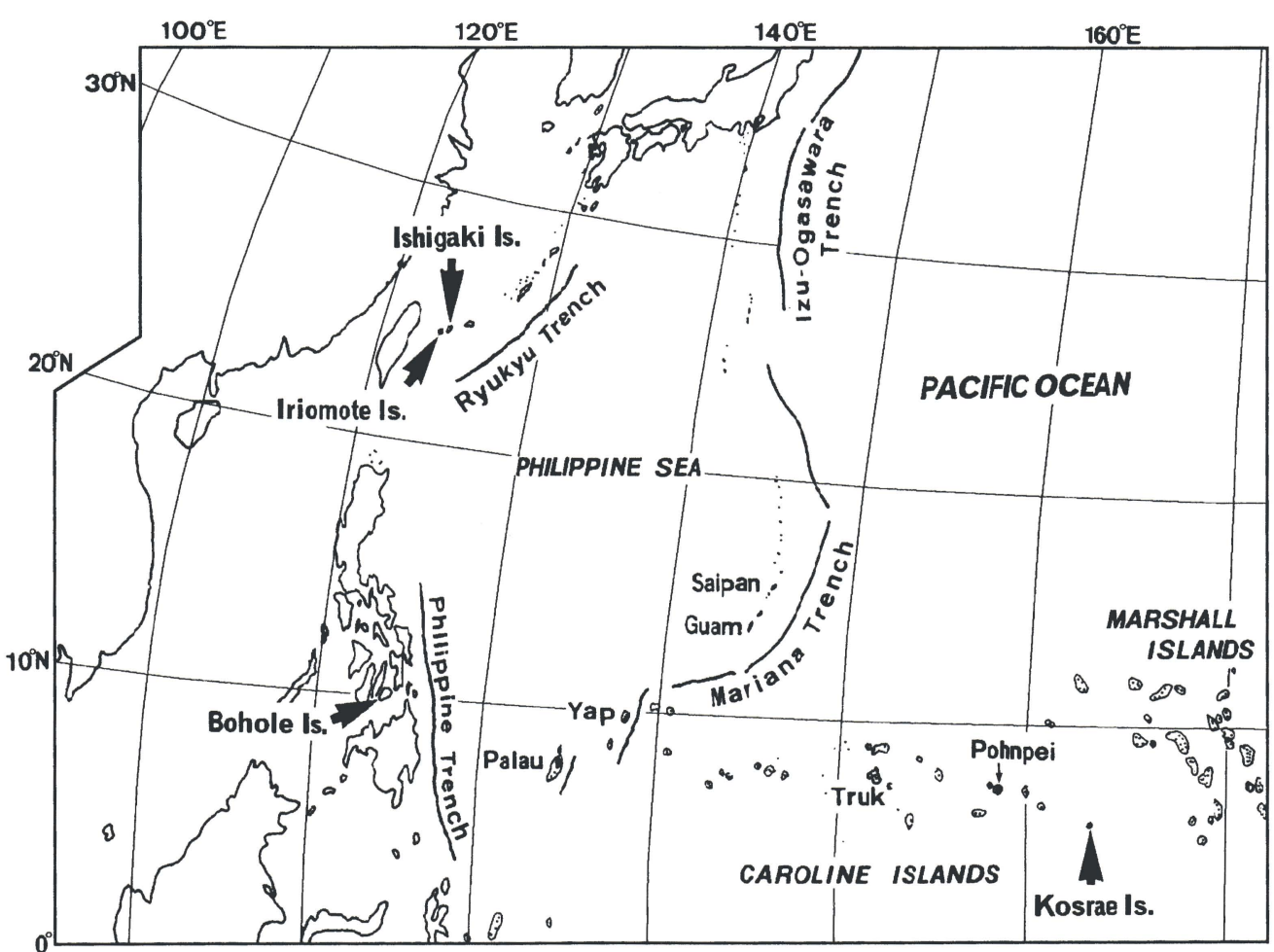

QAtoll or Barrier reef

図 1. 調查地域. [Fig. 1. Map showing the study areas]

う海面上昇も予測されており，その上昇速度の如何では，マングローブ林そのものの齐失も懸念 される。この様な現状の中でマングローブ林の適切な管理・保全を行うためには，森林を支える 立地の形成維持メカニズムを踏まえた議論を行う必要がある。マングローブ林は海岸平野やサン ゴ礁上の潮間帯に成立する森林であり，これらマングローブ林を支えている地形は現在の地形形 成プロセスの下で常に変動しており, 立地評価と将来予測を行うためには地形学的アプローチが 一つの有効な手段となる。大陸のマングローブ林は，主として大規模河川の河口域に広がり，そ の立地は河川による堆積・侵食作用によって形成・維持されているため (Thom et al., 1975; Woodroffe et al., 1989など), 微細な海面変化の影響は現れにくい。これに対し，小規模島嶼上 のマングローブ林は，河川の影響は小さく，海面の微細な変動が立地環境に大きな影響を与え る。

本稿では，ミクロネシアのコスラエ島，フィリピンのボホール島，および西表島と石垣島（図 1) のマングローブ林を例に, 立地の形成過程を海水準変動との関係から概説すると共に, 近年 の人為的インパクトの強度も考慮して, これら地域の森林環境の変化予測を行う。

\section{マングローブ立地の形成過程と相対的海水準変動}

\section{ミクロネシア, コスラエ島}

コスラエ島は, 北緯 5 度 16 22 分, 東経 162 度 54 分〜163 度 02 分に位置する, 裙礁で囲まれ た第三紀の火山岩からなる長径約 $15 \mathrm{~km}$ の島である。マングローブ林は島を取り囲むように分 布する。その面積は1562haに達し，ミクロネシアではポンペイ島に継ぐ 2 番目の面積を有する (MacLean et al., 1988)。この島のマングローブ林は, 大きな人為的インパクトを被ることなく 現在に至っているため, 比較的良好な森林環境が保たれている (写真A)。マングローブ林の立 

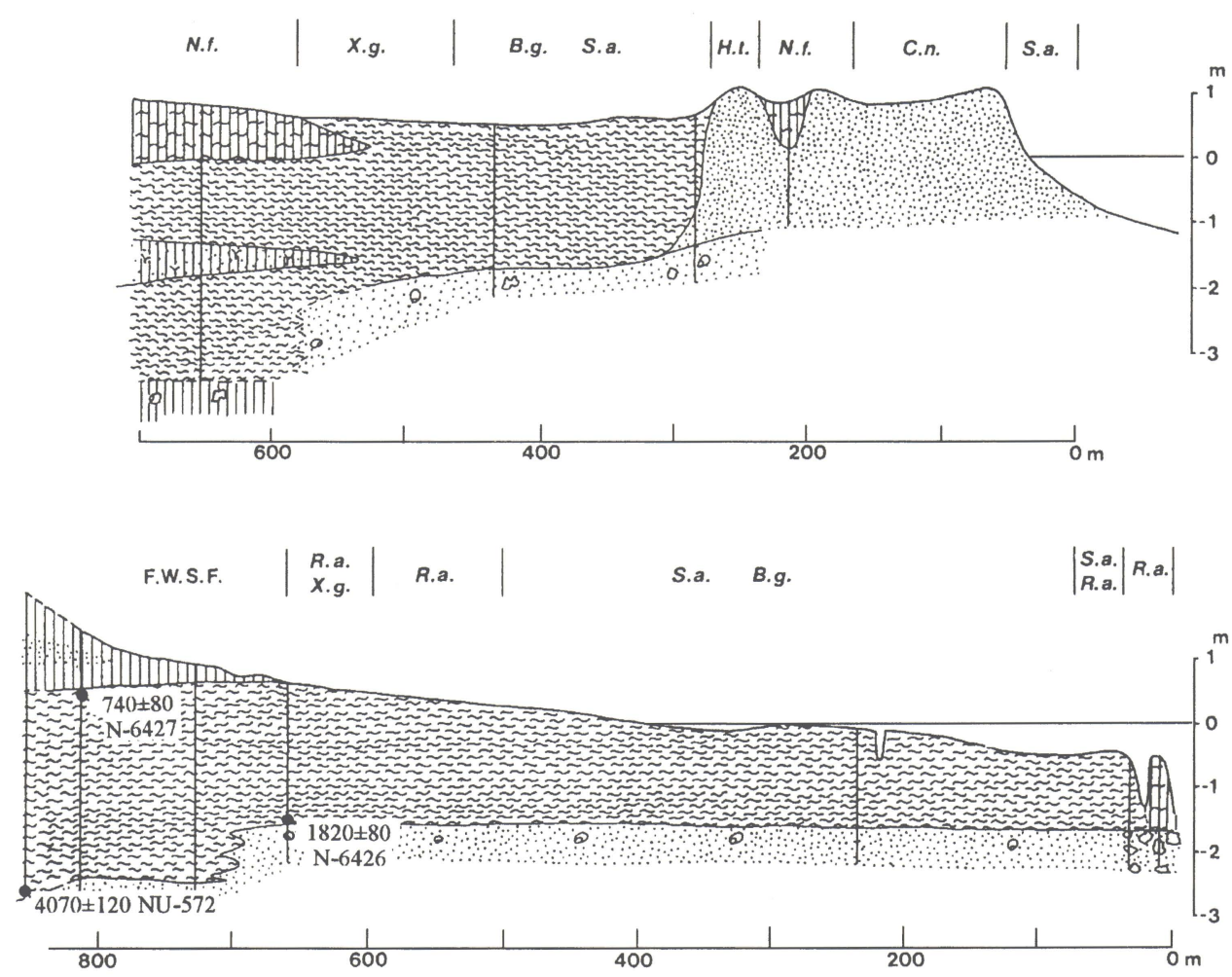

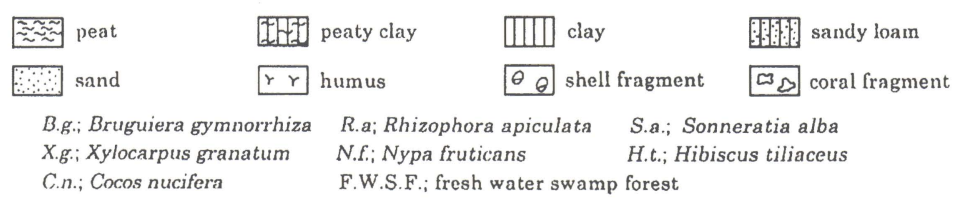

図 2.ミクロネシア，コスラエ島のデルタ型マングローブ立地の植生・地形・地質断面と マングローブ泥炭の ${ }^{14} \mathrm{C}$ 年代值. (Fujimoto et al, 1996) [Fig. 2. Vegetation, landform and geologic plofiles and radiocarbon ages of mangrove peats in the delta type mangrove habitats on Kosrae Island, Micronesia (after Fujimoto et al, 1996)]

地型は, デルタ・エスチュアリ型, 後背湿地・ラグーン型, サンゴ礁・干潟型の 3 タイプ (宮城, 1992) が認められる。

デルタ・エスチュアリ型は河口部に位置するにも関わらず，河成堆積物（無機物）の混入は少 なくマングローブ起源の泥炭質堆積物からなる。この泥炭層は内陸側では- $3 \mathrm{~m}$ 以深に達し, そ の下底部の ${ }^{14} C$ 年代值は $4000 \mathrm{yr}$ B.P. 以前の值を示す（図 2 )。現在マングローブ林が広がる海 側の部分には層厚 $2 \mathrm{~m}$ 内外の泥炭層が, $-2 \mathrm{~m}$ 以浅に堆積し, その下底部の ${ }^{14} \mathrm{C}$ 年年代值は2000 yr B.P. 以降の值を示す。

コスラエ島における完新世サンゴ礁の海抜高度は少なくとも $-0.05 \mathrm{~m}$ に達しており, 現生サン ゴの生息深度を考慮すると, 完新世の最高海水準は少なくとも $+0.65 \mathrm{~m}$ 以上に認定できる (Kawana et al., 1995)。その時期は年代測定值から $3700 \mathrm{yr}$ B.P.前後と推定されている。一方, こ の時期に堆積したマングローブ泥炭層は認められないことから，4000～3700 yr B.P.の間の海面上 昇（最大の見積もりで $10 \mathrm{~mm} / \mathrm{yr}$ ）に対してマングローブ林は泥炭の生産・蓄積のみでは立地を 維持できずに, 内陸側へ後退したと考えられる (Fujimoto et al., 1996)。

その後の海面低下期には，マングローブ林は海側へ前進した。2 000 yr B.P. 頃には海水準は現 
Phase 1

(low sea-level phase)

ca. 5000 yr B.P.

Phase 2

(rising sea-level phase)

ca. 4000 yr B.P.

Phase 3

(high sea-level phase) ca. 3500 yr B.P.

Phase 4 (low sea-level phase) ca. 2000 yr B.P.

Phase 5 (rising sea-level phase) ca. 1000 yr B.P.

Phase 6 present
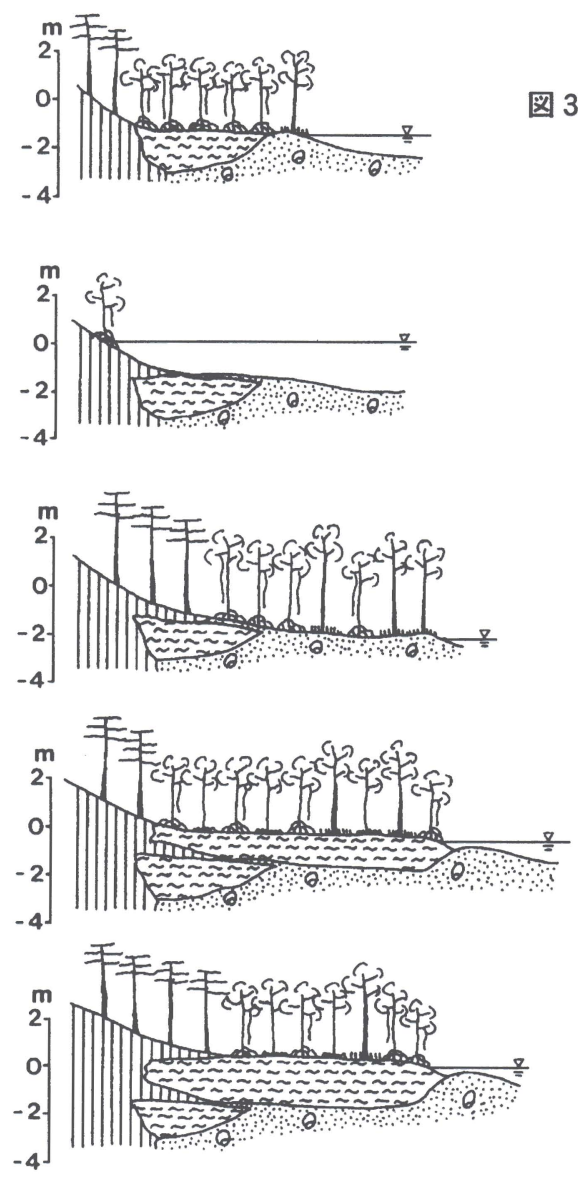

図 3、ミクロネシア，コスラエ 島におけるデル夕型マン グローブ立地の形成過程. (Fujimoto et al., 1996) [Fig. 3. Schematic representation of the geomorpholog ical evolution of the delta type mangrove habitats on Kosrae Island. (after Fujimoto et al., 1996)]

ह $\approx$ peat

海面下 $2 \mathrm{~m}$ 程度まで低下し, マングローブ林はこの海面低下で潮間帯となったそれまでの浅海 底面や礁原上に急速に拡大した。その後の $1 \sim 2 \mathrm{~mm} / \mathrm{yr}$ の緩やかな海面上昇に対して, マング ローブ林は泥炭を堆積することによって, 成立場所を移動させることなく, 現在までその立地を 維持している (図 3)。後背湿地・ラグーン型やサンゴ礁・干潟型のマングローブ林は，いずれ も 2000 yr B.P. 以降に形成されている。すなわち, 現在のマングローブ林のほとんどは $2000 \mathrm{yr}$ B.P. 以降に形成されたもので, $3700 \mathrm{yr}$ B.P. . 以前には後水期海進で形成された入り江内に, 幅の 狭い帯状の森林としてごくわずか存在するだけであったと考えられる (Fujimoto et al., 1996)。

フィリピン, ボホール島

ボホール島は北緯 9 度 34 分〜 10 度 09 分, 東経 123 度 46 分 124 度 37 分に位置する, 長径約 $90 \mathrm{~km}$ の石灰岩からなる島で, 周囲には隆起サンゴ礁からなる更新世海成段丘が発達する。マン グローブ林はこれらの海成段丘に挟まれた沖積低地上に広がるが, そのほとんどはニッパ Nypa fruticans 林からなる。ニッパ林を除くいわゆるマングローブ林は海岸沿いに帯状に分布するのみ 


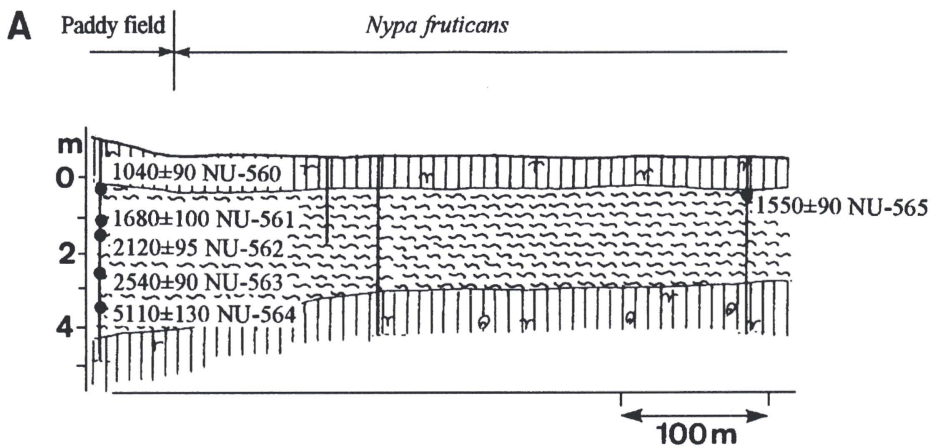

B

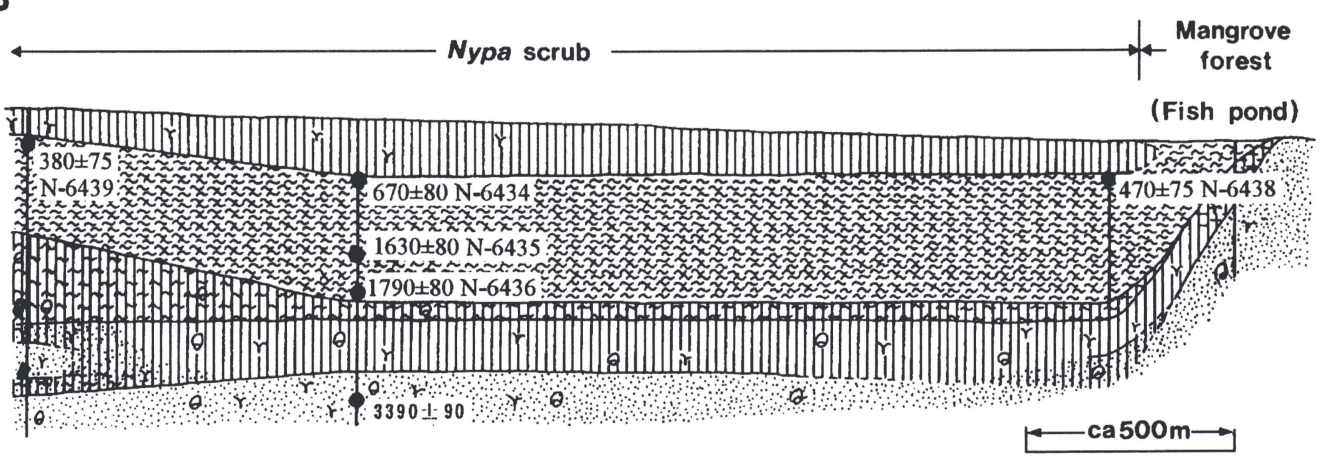

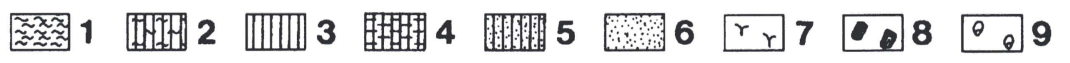

図 4.フィリピン, ボホール島のデルタ型マングローブ立地の植生・地形・地質断面と堆積 物の ${ }^{14} \mathrm{C}$ 年代值. $\mathrm{A}$ : 支谷 (内陸側), B : 本流低地, 1 : 泥炭またはローム質泥炭, 2 : 泥炭質粘土または泥炭質ローム, 3 : 粘土, 粘土質ロームまたはローム, 4 : シ ルトローム, 5 : 砂質ローム, 6 : ローム質砂または砂, 7 : 腐植, 8 : 木片, 9 : 貝款片, SW : 海側, LW : 内陸側 [Fig. 4. Vegetation, landform and geologic plofiles and radiocarbon ages of sediments in the delta type mangrove habitat on Bohole Island, the Philippines. A: branched valley plain, B: alluvial plain along the main stream, 1: peat or loamy peat, 2: peaty clay or peaty loam, 3: clay, clay loam or loam, 4: silt loam, 5: sandy loam, 6: loamy sand or sand, 7: humus, 8: wood fragment, SW: seaward, LW: landward.]

で, マングローブ泥炭上に成立する。現在その多くは養殖池に転用されており（写真C）, 良好な 森林環境を維持した林はほとんど見られない。周囲の斜面上にもほとんど森林は残されていない。

調査を行った島南東部のアバタン Abatan 川沖積低地では, ニッパ林下にマングローブ泥炭層 を覆って厚さ $1 \mathrm{~m}$ 前後の粘土層が堆積する (図 4)。泥炭層は, 内陸側で層厚 $4 \mathrm{~m}$ 程に達し, そ の下部から $5100 \mathrm{yr}$ B.P. の值が得られた。海側ではその層厚は $2 \sim 3 \mathrm{~m}$ 程となり, その最下部か ら $1800 \mathrm{yr}$ B.P. の值が得られた。ここでもコスラエ島同様, 泥炭層からは $3500 \mathrm{yr}$ B.P. 前後の值 を示す ${ }^{14} \mathrm{C}$ 年代值は得られていない。この様に, 表層の粘土層を除き, マングローブ泥炭はコス ラ工島と同様の堆積構造と堆積年代を示すことから, コスラエ島と同様の海水準変動傾向の下で 立地形成が進行したものと考えられる。本流沿いの沖積低地では, 粘土層直下の泥炭層上部から 400 700 yr B.P. を示す年代值が広範囲で得られており（図 4 - B), 粘土層はこの時期に一気に 広がったことがわかる。この粘土の急速な流入は, 集水域の森林伐採に伴う土壌侵食の進行に起 因する可能性が指摘できる。 

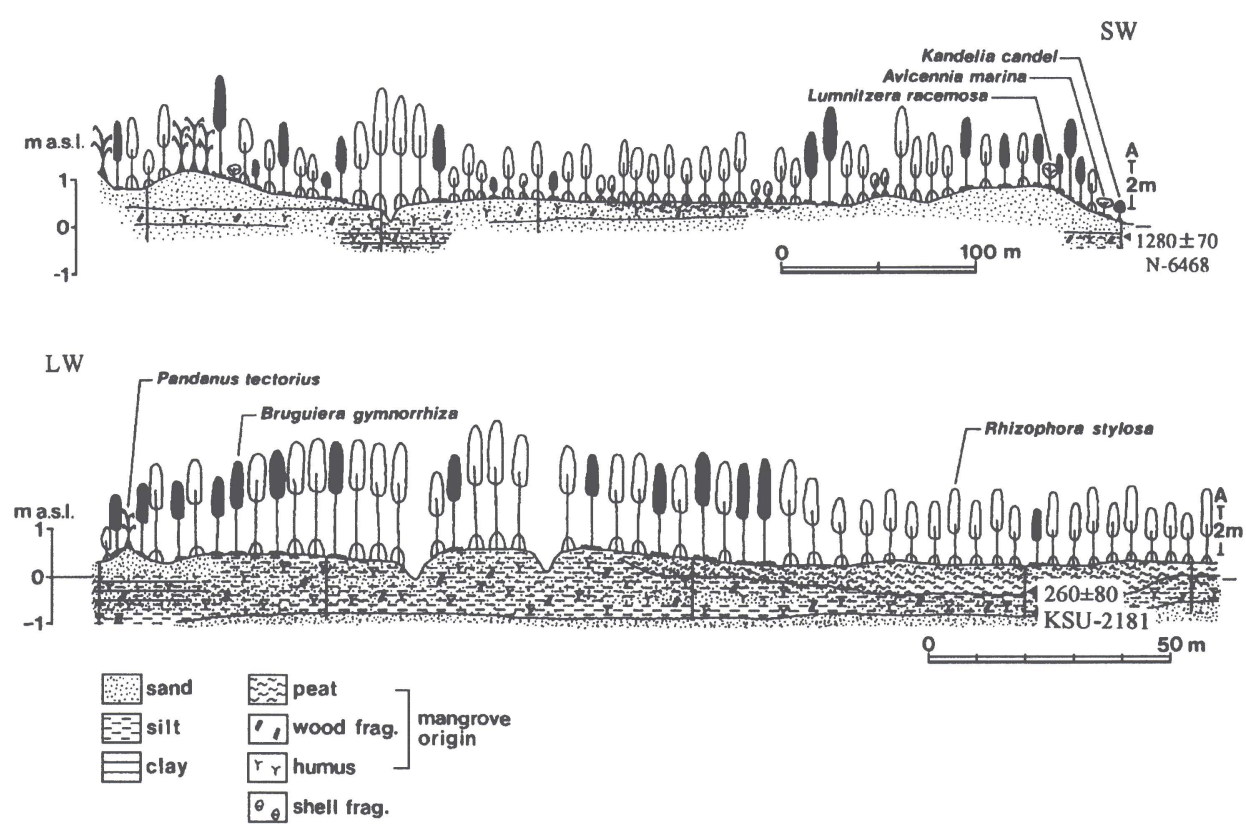

図 5. 西表島浦内川河ロマングローブ林の植生・地形・地質断面と堆積物の ${ }^{14} \mathrm{C}$ 年代值. $\mathrm{A}$ : 樹高スケール(Fujimoto \& Ohnuki, 1995) [Fig. 5. Vegetation, landform and geological plofiles and radiocarbon ages of sediments in the mangrove habitat at the mouth of the Urauchi River on Iriomote Island, Southwestem Japan. A: scale for trees (after Fujimoto \& Ohnuki, 1995)]

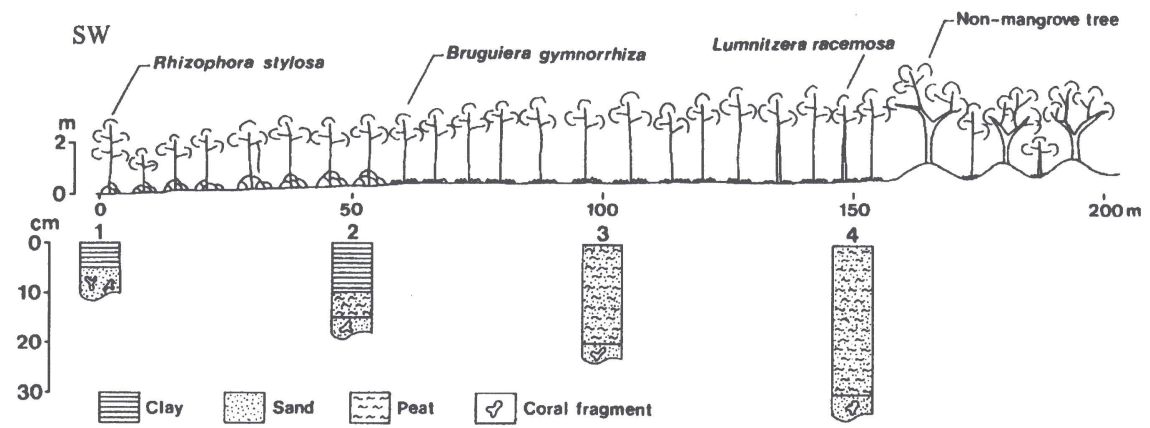

図 6. 石垣島名蔵川河ロマングローブ林の植生・地形断面と地質柱状図.（藤本ほか，1995） [Fig. 6. Vegetation, landform plofile and geologic columns in the mangrove habitat at the mouth of the Nagura River on Ishigaki Island, Southwestern Japan. (after Fujimoto et al., 1995)]

\section{西表島および石垣島}

西表島と石垣島は八重山諸島に属し, 両島の間には石西礁と呼ばれるサンゴ礁が発達する。西表 島は新第三紀の堆積岩からなる面積 $284 \mathrm{~km}^{2}$ 程の島で, 琉球石灰岩からなる更新世海成段丘が 海岸線に断片的に分布する。石垣島は面積 $221 \mathrm{~km}^{2}$ で, 中〜北部の丘陵・山岳地帯を除き，南部 を中心に主として琉球石灰岩からなる更新世海成段丘が広く分布する。マングローブ林面積は西 表島が約 400ha，石垣島が約 100ha で，両島で日本のマングローブ林面積の約93\%を占める（中 須賀, 1979)。

調査は西表島が北西部の浦内川低地で, 石垣島が西部の名蔵川低地で行った。両島とも現在の マングローブ林下の有機物層は層厚数 $10 \mathrm{~cm} \sim 1 \mathrm{~m}$ 程度と薄く (図 5, 6), 現在の位置にマン グローブ林が成立したのは数百年前と推定される。これらの有機物首は一部で泥炭質となるが, 


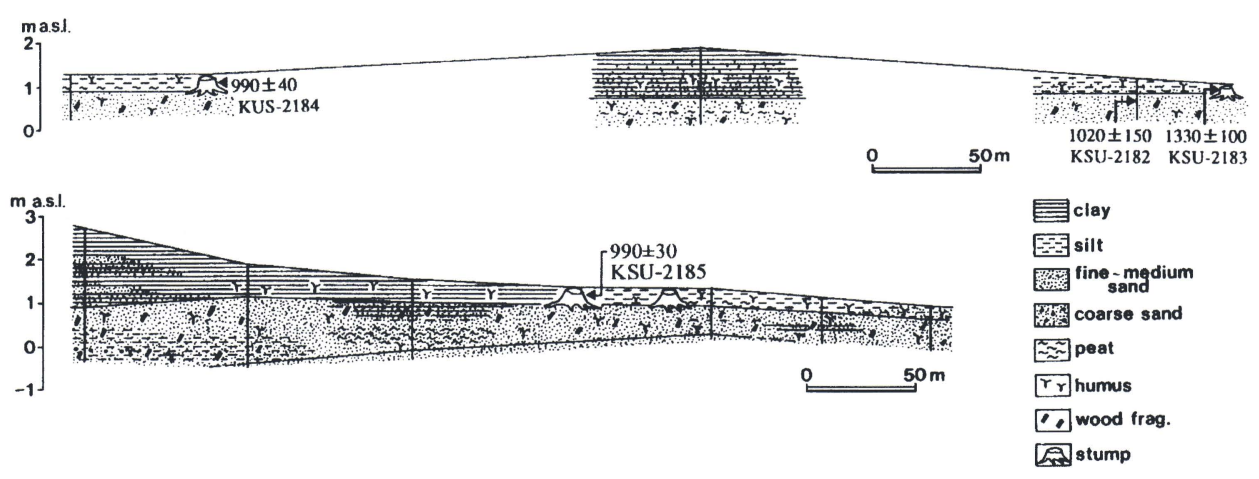

図 7. 西表島浦内川河ロマングローブ林背後の淡水湿地における地形・地質断面と堆積物 および埋積されたマングローブの根株の ${ }^{14} \mathrm{C}$ 年代値. (Fujimoto \& Ohnuki, 1995) [Fig. 7. Landform and geologic plofiles and radiocarbon ages of sediments containing mangrove organic materials and buried mangrove stumps in the fresh-water marsh behind the mangrove forest at the mouth of the Urauchi River on Iriomote Island, Southwestern Japan. (after Fujimoto \& Ohnuki, 1995)]

砂質堆積物であることが多い。 浦内川マングローブ林の海側林 縁部には, 自然堤防堆積物で埋 積されたマングローブ有機物含 有層が存在し, その上限の堆積 年代は $1280 \pm 70 \mathrm{yr}$ B.P. を示す。 これはマングローブ林が, この 時期に一旦内陸側へ後退したこ とを示していると考えられる。

西表島の浦内川低地では, 現 在は淡水湿地となっているマン グローブ林背後の沖積層中に, シルト〜粘土からなる淡水湿地 堆積物に覆われた, 約 $1000 \mathrm{yr}$ B.P. に離水したマングローブの 根株および有機物を伴う砂質堆 積物が広く認められた（図 7)。 この砂質堆積物は, パイライト Pyrite $\left(\mathrm{FeS}_{2}\right)$ を大量に含むこと から海成層であることが確認さ れた (Fujimoto \& Ohnuki， 1995)。石垣島の名蔵川低地で は, マングローブ林背後に 2 列 の旧砂州が認められ，これらの 後背湿地堆積物中に, いずれも

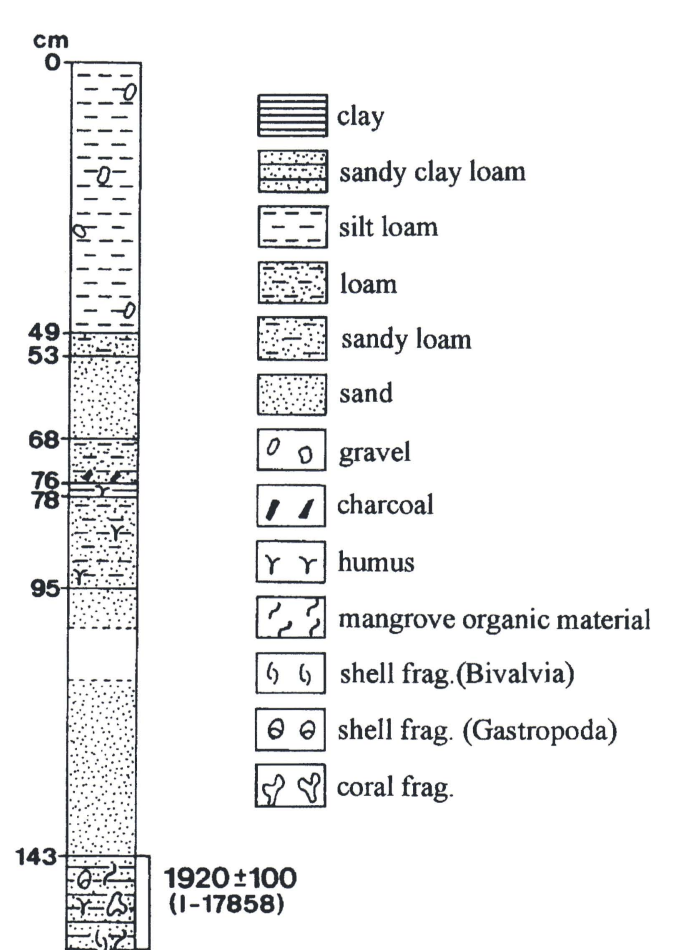

図 8. 石垣島名蔵川河ロマングローブ林背後の 淡水湿地における地質柱状図と堆積物の ${ }^{14} \mathrm{C}$ 年代値. (藤本ほか, 1995) [Fig. 8. Geologic column and radiocarbon age of the sediments containing mangrove organic materials in the fresh-water marsh behind the mangrove forest at the mouth of the Nagura River on Ishigaki Island, Southwestern Japan. (after Fujimoto et al. 1995)] マングローブ有機物含有層の存 在が確認された。そのうち海側 のものの離水年代は得られなかったものの，内陸側のマングローブ有機物含有層からは約 2000 yr B.P. に離水したことを示す ${ }^{14} \mathrm{C}$ 年代值が得られた（図 8)。これらの事実から，八重山諸島で は $1000 \mathrm{yr}$ B.P. および $2000 \mathrm{yr}$ B.P. 頃に相対的な海面低下が起こり, それに伴ってマングローブ 
林も海側に移動した可能性が指摘できる (Fujimoto \& Ohnuki, 1995 ; 藤本ほか, 1995)。八重山 諸島一帯は，500～1000年間隔で巨大津波を伴う巨大地震が発生してきており, 約 1000 年前と 2000 年前には特に大きな地震が発生したと考えられていることから（河名・中田，1994），相対 的海面低下は地震に伴う間欠的な地盤隆起に起因したものである可能性が高い (Fujimoto \& Ohnuki, 1995)。

近年は, 農地造成に伴う赤土流出の影響で, 干潟上で急速な堆積が進行しており (写真 $\mathrm{E}, \mathrm{F}$ ), これに伴うマングローブ林の急速な海側への拡大が認められている（山内ほか，1995)。また， 空中写真判読から, 1960 年代後半から 1970 年代半ばにかけて観測された $20 \mathrm{~cm}$ 程の相対的な海 面上昇に対して, マングローブ林の海側林縁部の後退は認められなかったものの, 内陸側へは顥 著な侵入が起こったことが認められている(Fujimoto and Ohnuki, 1995)。

\section{マングローブ林の立地変動の将来予測}

太平洋島嶼域のマングローブ林立地は, 相対的海水準変動の影響を多大に被りながら形成されて きたことが明らかになってきた。また, ある程度までの海面上昇速度に対しては, 主としてマン グローブ泥炭を堆積させることによって，その立地を維持できることも明らかにされた。その限 界速度はそれぞれの地域におけるマングローブのバイオマス生産量と外部からの無機物供給量に よって決まってくる。

コスラエ島のような熱帯湿閏地域では，マングローブ泥炭堆積最大速度は $5 \mathrm{~mm} / \mathrm{yr}$ 程度と見 積もられる (Miyagi et al., 1995)。温暖化に伴う海面上昇速度がこれを上回った場合にはマング ローブ林の後退現象が起こることが予測される。 コスラエ島東岸の波浪の影響を受けやすい幅 の狭い礁原上には，一列にきれいに並んだ Sonneratia alba をみることができる (写真B)。この 地域の S. alba は, 通常パイオニア樹種として砂質堆積物上に成立する。しかし, この礁原上に はサンゴ磁を除くと堆積物は認められない。この状況から, かつては砂質海浜堆積物が現在より 海側まで張り出しており, これらの S. alba はその堆積物上に定着したものの, その後の海岸侵 食によってそれが除去され，礁原上に取り残されたものと考えられる。この北側の礁原上では, 本来なら潮汐のおよぶ土地には生育できないはずのココヤシの根株が，潮間帯に取り残されてい るのが認められた。これらの事実から, コスラ工島では近年相対的な海面上昇が進行しており, 波浪の影響を被りやすい場所では, 海岸侵食という形で既にその影響が現れているものと考えら れる。海面上昇傾向が継続するならば，まずは波浪の影響を被りやすいサンゴ礁・干潟型のマン グローブ林において, 海側林縁部の後退減少が進行するであろう。

ボホール島では最近数百年間の集水域からの急速な粘土の流入に伴い，内陸側からニッパ林が 拡大してきた。粘土からなるニッパの立地では, 現在他のマングローブ樹種はほとんど見られず, わずかに点在する Avicennia も衰退傾向にある (写真D)。海面が上昇した場合には, 本来ならマ ングローブ林の内陸側への侵入が起こると予想されが, 上記の様に, 粘土に覆われたニッパ林域 は他のマングローブ樹種の立地としては不適切な土壌環境にあると考えられ，海面が上昇したと しても, 直ちに他のマングローブ樹種の侵入が始まるとは考えにくい。従って, マングローブ林 域は海側から徐々に縮小していくものと推定される。

八重山諸島では, 赤土流入は現在ではマングローブ林の拡大に貢献しているように見えるが， いずれは海側の限界点まで前進し, 一方, 内陸側からは淡水植生の侵入が進行し, 面積的には縮 小に転じるものと予想される。熱帯湿潤地域に比べるとバイオマス生産量はかなり劣ると考えら れることから，海面上昇に対しては，熱帯地域以上にその影響が顕著に現れるであろう。 

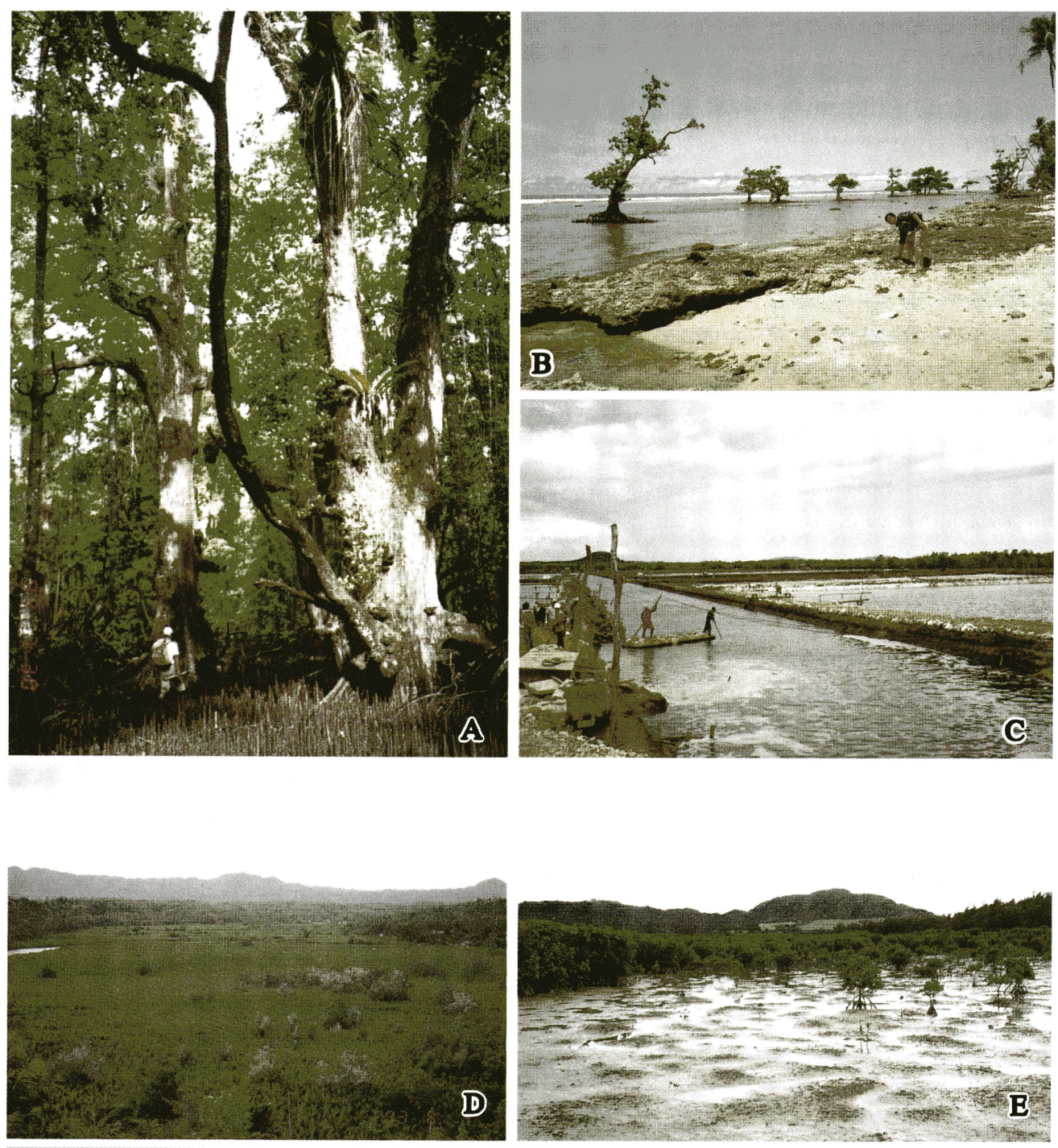

写真 A .ミクロネシア，コスラエ島のマングロー ブ林. Rhizophora apiculata や Bruguiera gymnorrhiza が優占する林の中に, このような Sonneratia alba の巨木が点在している.

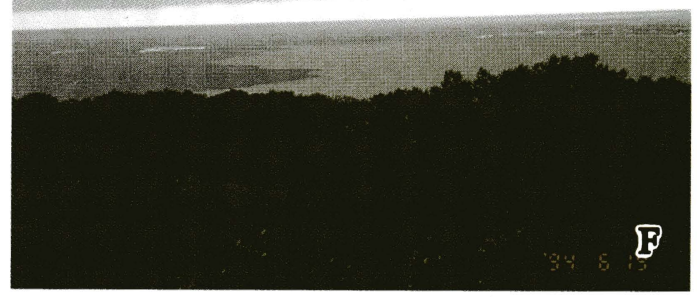

写真 B. コスラエ島の礁原上に一列に取り残され た Sonneratia alba. 近年の海岸侵食の結果, 礁 原上の堆積物が除去され, ケーブル根が露出 している.

写真 C. フィリピン, ボホール島のマングローブ 林を切り開いて建設された大規模養殖池.

写真 D. ボホール島のニッパ Nypa fruticans 林と その中に点在する衰退傾向にある Avicennia.

写真 $\mathrm{E}$. 石垣島名藏川河口干潟に堆積した「赤土」 とその堆積に伴い海側に拡大しつつあるヤエ ヤマヒルギ Rhizophora stylosa 林.

写真 F．集中豪雨に伴(河口から流出する「赫土」 (石垣島宮良川河口). 
おわりに

過去に起こった $10 \mathrm{~mm} / \mathrm{yr}$ 程の速度で進行した急激な海面上昇に対しては、マングローブ林は その面積を急速に狭めながら, 一気に内陸側入後退した。しかし, $2 \mathrm{~mm} / \mathrm{yr}$ 程の緩やかな海面 上昇に対しては，マングローブ泥炭に代表されるような有機物層を形成することにより，立地を 維持してきたことが明らかになった。太平洋島嶼域では, この有機物層の層厚は, 多くの場合 2 〜 $3 \mathrm{~m}$ で, 現海面下 1.5 $2 \mathrm{~m}$ 程に達している。海面安定期においても, マングローブ林が 徐々に海側へ前進していく場合には, 地盤高がマングローブの生育可能な中等潮位から高潮位の レベルまで上昇する間に，そこでの潮位差に応じた層厚の有機物層が形成される。この様に，マ ングローブ林は, 地下部に有機物層を形成することにより, 炭素蓄積の場として機能し, 地球環 境の形成・維持に対して重要な役割を担っている可能性が指摘できる。

マングローブ林背後の沖積低地上には，泥炭湿地林や淡水湿地林が広く分布する場合も多い。 これらも含めた熱帯低湿地林の地下部に蓄積されている炭素量の推定や, 将来に予想される海面 上昇に伴う炭素蓄積量の変化予測に資する具体的資料の蓄積は未だ不十分であり, 今後の更なる 研究成果の蓄積が必要である。熱帯低湿地林の森林環境の保全は, 沿岸域の生態系の保全や海岸 防備林としての機能の維持に貢献するのみならず，地球環境の形成・維持に対しても極めて重要 な意義をもつのである。

謝辞 本稿は, 平成 $5 \sim 7$ 年度文部省科学研究費補助金（国際学術研究）「海面の急激な上昇時 におけるマングローブ林の立地の維持」(課題番号 : 04041020, 研究代表者 : 岐阜大学 菊池多 賀夫), 平成 $2 \sim 4$ 年度科学技術庁科学技術振興調整費による生活・地域流動研究「マングロー ブ林を中心とした生態系の解明に関する研究」(地域中核オーガナイザー : 琉球大学 国府田佳 弘), 財団法人日本自然保護協会プロ・ナトゥーラ・ファンド第 4 期助成（平成 5 年度）研究 「サンゴ礁干潟の環境変化と保全」（研究代表者：群馬大学 山内秀夫）で得られた研究成果を取 りまとめて作成したものである。これらの調査研究の機会を与えて下さった諸機関ならびに関係 する皆さんに厚く御礼申し上げます。

\section{引用文献}

Fujimoto, K. \& Ohnuki, Y. 1995. Developmental processes of mangrove habitat related to relative sea-level changes at the mouth of the Urauchi River, Iriomote Island, Southwestern Japan. Quarterly Journal of Geography 47: 1-12.

藤本 潔・山内秀夫・目崎茂和・長谷川均・前門 晃, 1995. 石坦島名蔵川低地とマングローブ 林の形成過程. 日本地理学会予稿集 47 : 384 385.

Fujimoto, K., Miyagi, T., Kikuchi, T. \& Kawana, T. 1996. Mangrove habitat formation and response to Holocene sea-level changes on Kosrae Island, Micronesia. Mangroves and Salt Marshes 1: 47-57.

河名俊男・中田 高, 1994. サンゴ質津波堆積物の年代からみた琉球列島南部海域における後期 完新世の津波発生時期. 地学杂誰誌 $103: 352-376$.

Kawana, T., Miyagi, T., Fujimoto, K. \& Kikuchi, T. 1995. Late Holocene sea-level changes and mangrove development in Kosrae Island, the Carolines, Micronesia. In: Kikuchi, T. (ed.), Rapid Sea Level Rise and Mangrove Habitat, 1-7. Institute for Basin Ecosystem Studies, Gifu University, Gifu.

MacLean, C. D., Whitesell, C. D., Cole, T. G. \& McDuffie, K. E. 1988. Timber resources of Kosrae, Pohnpei, Truk, and Yap, Federated States of Micronesia. Resource Bulletin PSW-24, 8 pp. Pacific Southwest Forest and Range Experiment Station, Forest Service, U.S. Department of Agriculture, 
Berkeley.

宮城豊彦, 1992. マングローブハビタットの土地管理. 地形 13 : 325-331.

Miyagi, T., Kikuchi, T. \& Fujimoto, K. 1995. Late Holocene sealevel changes and the mangrove peat accumulation / habitat dynamics in the western Pacific area. In: Kikuchi, T. (ed.), Rapid Sea Level Rise and Mangrove Habitat, 19-26. Institute for Basin Ecosystem Studies, Gifu University, Gifu. 中須賀常雄, 1979. マングローブ林の林分解析. 琉球大学農学部学術報告 $26:$ 413-519.

Thom, B. G., Wright, L. D. \& Coleman, J. M. 1975. Mangrove ecology and deltaic-estuarine geomorphology: Cambridge Gulf-Old River, Western Australia. Journal of Ecology 63: 203-222.

Woodroffe, C. D., Chappell, J., Thom, B. G. \& Wallensky, E. 1989. Depositional model of a macrotidal estuary and floodplain, South Alligator River, Northern Australia. Sedimentology 36: 737-756.

山内秀夫・長谷川均・目崎茂和・前門 晃, 1995. サンゴ礁干潟の環境変化と保全. 日本自 然保護協会（編），プロ・ナトゥーラ・ファンド第 3 期助成成果報告書 ， 8-17. 